\title{
Reinforcing Public University Student's Worship Education by Developing and Implementing Mobile- Learning Management System in the ADDIE Instructional Design Model
}

\author{
https://doi.org/10.3991/ijim.v14i02.11380 \\ Yusuf Hanafi ( ${ }^{\bowtie}$, Nurul Murtadho, M. Alifudin Ikhsan, \\ Tsania Nur Diyana \\ Universitas Negeri Malang, Malang, Indonesia \\ yusuf.hanafi.fs@um.ac.id
}

\begin{abstract}
This research aimed to develop and explore the effect of the implementation of mobile-Learning Management System called e-BBQ, in guiding students' worship. This study was conducted in Universitas Negeri Malang in odd semester of 2018-2019 academic year by referring to ADDIE instructional design model. The implementation stage was carried out by onegroup pretest-posttest design. The research subjects were 100 students selected by using randomized sampling. As a result, e-BBQ developed is in the form of application and website with some menus including reading Al-Qur'an, worship, exercise, and $\log$ in instructor. Formative evaluation through validation by expert of media, language, and topics, as well as students and instructors through trial assay, showed that the e-BBQ gave a positive effect, and students' worship skill improved significantly. In addition, e-BBQ was considered as an interesting Islamic learning media that enabled learning more joyful and encouraged students' learning motivation.
\end{abstract}

Keywords-Islamic religious education, Mobile Learning, Learning Management System, worship.

\section{Introduction}

The knowledge of reading Qur'an and praying is fundamental and compulsory that should be comprehended by Muslim. In a day, Muslims should pray five times in which they should read Al-Qur'an. How a Muslim prays is a crucial parameter of religious observance in Islam [1]. In another side, reading Al-Qur'an has characteristics where each letter has different spelling [2], and reading mistake could cause different meaning [3]. Therefore, learning of worships such as praying and reading AlQur'an is pivotal in Islamic religious education. This learning emphasizes correct and order worship practices in terms of both reading and motion.

Up to now, learning of praying and reading Al-Qur'an is carried out by conventional ways. Instructors show the examples through demonstration method, and their 
students follow them. This method is appropriate if it is applied in learning of worship education, but instructors may not continuously demonstrate so that the students can understand well in one meeting. For example, when instructors show an example of motion in praying, the repetition of the movement is needed so that the students can understand well. However, if students cannot understand after repetition of examples, the instructors have limited energy to demonstrate how to pray continuously. Another problem is that sometimes, students cannot strongly memorize and tend to be wrong in practicing independently after learning. This case causes students' exercise cannot run well, and their knowledge and worship practice cannot develop fast.

In the context of higher education, the number of hours of Islamic religious education is considered having a small proportion compared to hours of science learning. This condition has caused a problem where students are less in mastering religious teaching, and there will be no balance between science and religion. Some universities respond to this issue by adding religious programs separated from class lecture in each faculty in the form of centered religious education. Alba [4] explained that this step is excellent since it will eliminate secular campus label and enhance students' religious enthusiasm rated very low recently. Providing facility in the form of education is believed being able to highly contribute to develop students' religious character [5]. Another problem is that too many students studying in class. Although the practice of worship is conducted in small groups, it is carried out together in one place so that it is challenging to improve students' active participation. Students often encounter unconfidence and fear of being ridiculed by their peers since they have not been able to master how to worship in Islamic religion at their adulthood age.

The problems arising in Islamic religious education course are challenges that should be resolved as soon as possible from the aspect of both religious urgency and education. This research tried to view this challenge as an opportunity to rethink and redesign an appropriate pedagogy by taking into account the technological aspect. One of the challenges of Islamic religious education in higher education is the absence of preparation to meet global challenges [6]. In this digital era, technology cannot be avoided to improve the effectiveness of teaching [7]. Technology is an essential component of school curriculum in this era [8], including in Islamic religious education [9]. Syah [10] explained that the integration of technology is one of right strategies in strengthening Islamic religious education in an institution.

Recent advances in computer technology have created the most contentious problems related to Islamic religious education in higher education [11]. The technology of multimedia is believed as being able to help students construct Islamic knowledge effectively [12]. Furthermore, multimedia can provide conducive atmosphere of Islamic religious learning and teaching and visualize information dynamically and interestingly [13]. An example of using multimedia is uploading video that can visualize the procedure for reciting Al-Qur'an and praying in which there are process, terms, and concepts. By technology, learning will be not only more effective in transferring knowledge but also able to support students to be critical thinker in understanding key Islamic issues [12].

Most universities provide a platform for learning in the form of a learning management system (LMS) for all subjects. LMS can support interaction between students 
and lecturers. However, this platform is considered too dependent on computer viewed impractical and high-cost. In another side, mobile devices are regarded lowcost and portable, suitable for use in extracurricular activities and have more exciting design [14] [15]. The advantage of learning using mobile or known as mobile learning (m-learning) is combining educators, students, and content whenever and wherever [16]. Comfort and flexibility in use become the main advantages of m-learning [17]. The benefits of mobile learning integration far exceed the limitations of these devices [18], especially in providing facility of individual feedback that perhaps gives positive effect on performance [19]. This view has led many researchers to develop mobile learning in the past decade.

Nowadays, mobile learning has become a trend in education in many countries [20] [21] and has been applied in various fields [22]. The development of mobile learning in Indonesia is categorized in infant stage and far left-behind from developed countries. In one side, Indonesia has significant potentials to apply mobile learning. The community of education has recognized that learning assisted by mobile devices are useable for education improvement and continual [23]. Lately, efforts to develop mobile learning in Indonesia have been increasingly proven in various educational fields such as biology [24], economy [25], mathematics [26], and language [27]. Those studies have proven that mobile learning could improve students' learning outcome. In Islamic religious education, especially Al-Qur'an, mobile learning develops rapidly as well [28].

Behind the advantages and success of mobile learning, there is a criticism of the development of this method. Mobile learning is considered only being able to convey material, but cannot facilitate students how to be independent learners [29]. Gikas \& Grant [30] revealed that mobile learning could weaken interaction between users. In addition, Boyinbode \& Ng'ambi [31] explained that mobile learning has weakness where educator's participation is limited. From some pieces of literature, it can be said that the weakness of mobile learning which is the minimum interaction between users becomes the advantage of LMS. On the contrary, the weakness of LMS that is the limited devices, becomes the advantage of mobile learning. As explained by Bahrdwaj \& Jain [32], the main advantage of the use of mobile learning is accessing information in any situations, especially when the support of computer devices is absent. Cellular applications have been deployed to help the use of LMS by students at the international level [33], [34]. LMS that can be accessed by students and faculties to the learning through mobile devices is called mobile learning management system (m-LMS) [35].

Therefore, this m-LMS development research aimed to combine the advantages of LMS and mobile learning with the hope of being able to provide more profound learning experience in Islamic religious education learning. M-LMS is also expected to provide information about worship procedure in any situations such as traveling since, in Islam, praying must be done wherever we are. This m-LMS method is chosen since students are highly enthusiastic to mobile technology [36]. In this view, universities that previously used LMS have a significant opportunity to shift to m-LMS platform. The previous research found that experience by using e-learning system was a predictor factor in decision making by using m-Learning [37]. Beyond these advantages and 
weaknesses, m-LMS research is limited, especially in Islamic religious education subject.

This research aimed to explore students' perception of the use of m-LMS in worship education learning in Islamic religious education subject since the limited use and advantage of mobile devices could arise students' negative responses and make them dislike the use of technology [38]. In this work, the effectiveness of m-LMS in improving students' learning outcome was evaluated as well. An experiment was conducted in Islamic religious learning in higher education to test the effect of the use of m-LMS on students' performance in the ability to read Al-Qur'an and worship based on the procedures in Islamic religion.

By developing this m-LMS application, it is expected to help educators in selecting educational application which is appropriate for students' characteristics. Based on the findings of Papadakis \& Kalogiannakis [39], although there are a lot of educational application choices, the educators are difficult in finding the right application for their students because many applications were not developed based on targeted age characteristics [40] [41]. The results of this study are expected to change Islamic religious education learning to be more systematic and optimal [9]. This research proved that some barriers in integrating ICT into Islamic religious education could be settled [42]. In addition, this step will stimulate innovation in Islamic religious learning integrated with technology since the use of ICT in the Islamic religious education subject is still unwell categorized [43].

For Islamic religious education, tahsin tilawah model is considered as an ideal learning strategy that can stimulate students to be actively involved in learning. Tahsin tilawah is regarded as a critical element in practicing reading Qur'an centered to students (active method). The goal of tahsin tilawah implementation is to assist students in developing their reading Qur'an skill based on tajweed rules. This tahsin tilawah is based on Talqin-Talqid that is almost similar to repeated reading in language learning [44]. In worship learning such as ablution and prayer, the same principles are applied; first, the instructor will give examples and students will be asked to imitate the examples.

In this research, this tahsin tilawah method was implemented and integrated with m-LMS. This integrated technology is expected to support the shift of traditional method to student-centered learning strategy [12]. Islamic philosophy presents the urgency of active learning since Islamic education is not only about transferring knowledge but also refining Muslim students' whole life [45]. Importantly, we emphasize that the use of mushaf is still maintained in m-LMS implementation to keep the love of Qur'an. The negative impact of modernization of reading Qur'an learning method is technology can potentially replace mushaf, and this case should be avoided. Many Muslim scholars worry about the bad effect of the use of modern ideas [46] that they are reluctant to use in Islamic learning [47]. This study could prove that the use of contemporary technology could be implemented hand in hand with the conventional method. Aziz, Abdullah, Ahmad, Mushim, \& Shahrudin [48] explained that modern technology method still needs to refer to the traditional method in Qur'anic learning.

Furthermore, this paper explains the process and results of research and development of m-LMS in three parts. The second part describes the process design of devel- 
opment and implementation of m-LMS started from analysis to evaluation. The third part explains the results of formative and summative evaluations of $\mathrm{m}$-LMS implementation. The fourth part presents discussion and conclusion.

\section{Process Design}

Mobile Learning Management System (m-LMS) that we call e-BBQ was developed based on the ADDIE Instructional Design Model (IDM). ADDIE stands for Analysis, Design, Develop, Implement, and Evaluate [49]. ADDIE is often described as a linear model, but this IDM is iterative and cyclic; evaluation stage was carried out in each stage [50]. ADDIE can be used in two ways namely the framework in developing learning and especially as a process of making multimedia [51]. ADDIE is often employed in the development of multimedia, especially in Indonesia. The practical application in any situations and natural flow from one stage to another stage are frequently delivered reasons for choosing ADDIE as process by researchers. Giannakas, Papasalouros, Kambourakis, \& Gritzalis [52] recommended ADDIE as one of the right IDMs to detail learning experience in using mobile learning to improve students' skill. Previous research and development of mobile learning using ADDIE process have proven that this process design could improve students' skill [53], [54], including in Islamic religious education [20].

\subsection{Analysis}

The analysis is initial stage used as the basis for consideration in developing. Need analysis was carried out to define teaching issues. The analysis was done by seeing two things. First is students' condition or characteristics (worship skills). Based on the data obtained from measuring worship skills done by teachers and researchers, it can be concluded that students' scores were categorized as good enough, but their skills related to religious ceremonies should reach as perfect level as possible. In addition, there is still a big gap where a group of students has almost excellent skills, and another group of students has deficient skills. The similar result was also shown by Abouelsaadat [55] finding that adult still got mistakes in worship, especially prayer. This condition is possible because some such topics as basic knowledge to read Qur'an, ablution and prayer procedures are only taught in primary school level and untaught again in secondary school levels. Such condition is also supported by some studies on learning media of ablution and praying mostly for primary school students like conducted by Sotar, Suardinata, \& Irawan [56], Chomariyah, Fakhruddin, \& Supriyadi [57], and Hamzah, Halim, Hassan, and Ariffin [58].

The second was seeing the problems in worship education learning activities, especially learning management through interview to students and observation. As the results, some students complained the traditional learning system so that they were less interested in learning that did not follow the advance of educational technology by emphasizing instructor-centered learning. Nawi, Jamsari, Hamzah, Sulaiman, \& Umar [59] stated that Islamic religious education is categorized as poor in applying 
various learning methods because of lecture and class methods often used. Although the evaluation results showed that this method was positive enough in enhancing students' worship skills, the last semester evaluation held by the institution also indicated some learning management problems including poor assessment access and archiving, unconstructive feedback, and complicated learning meeting administration due to manual procedure.

Other aspects analyzed in this stage are related to the teaching environment, especially the rule of learning and technology needed. The results showed that worship education learning has not integrated qualified technology. Some instructors and students delivered their wish to have soon the development of technology that can help them in improving learning quality. Some of them also stated that they expected that mobile learning nowadays that has been developed in scientific learning can also be applied in worship learning in Islamic religious education course. From the aspect of technology availability, almost all students have smartphone. Students are familiar with technology products used in daily activities. This condition requires all parties to be involved in religious education to find right solution. One of the solutions is by developing mobile learning that can be integrated into worship education activities.

These data inform that the improvement of worship education teaching in Islamic religious education subject could be integrated with technology that can solve learning management problems and improve students' skills. Therefore, m-LMS will be effective, efficient, and significant sources in enhancing worship education learning in higher education.

\subsection{Design}

Design is the stage where all research plannings are conducted. In this stage, researchers determined components that should be uploaded in m-LMS that would be developed. In addition, this step also determined the learning goal, learning design by using m-LMS, and evaluation instrument to measure the success of development. All designs were carried out based on formative evaluation by discussing with Islamic religious educational experts with the hope that the developed m-LMS would be appropriate for students' need in Islamic religious learning.

Based on skills needed by students, two main topics were included in e-BBQ namely reading Qur'an learning and worship education including ablution, prayer, fasting, and almsgiving. This topic presentation is also completed with speech recognition and login of the instructor as the characteristics of technology development in Islamic religious learning. Research conducted by Alqahtani \& Mohammad [60] explained that mobile learning with the speech recognition component has greatly assisted students in learning Al-Qur'an verses easily and independently. Technology supports the application of the Tahsin Tilawah method. This ability is very helpful for students to master the ability to worship, especially prayer because in prayer there is reading the Qur'an. In addition, the login menu for instructors on e-BBQ aims to facilitate instructors in assessing and providing information on student's learning progress. This menu will be linked to a website that has been synchronized with the university database. This menu is also the main differentiator of mobile learning in general and 
traditional LMS. A number of researchers revealed that the failure of mobile learning in improving student learning was due to only focusing on the delivery of material, but not facilitating how they learn. Furthermore, Sharples, Arnedillo-Sánchez, Milrad, \& Vavoula [29] explained that to overcome those failures, mobile learning should be designed not only to emphasize the involvement of students in individual learning but also to take into account stakeholders in a learning environment. With this login of instructor, it is expected that e-BBQ can anticipate the causes of not achieving the learning objectives using mobile learning.

The learning objectives that are set namely being able to practice makharijul letters and shifatul letters, ghunnah, and long-short patterns, read the Qur'an precisely and fluently, memorize prayer in every worship procedure, especially prayer, and practice ablution, prayer, almsgiving, and fasting properly. Meanwhile, the learning design of each meeting consists of two sessions namely, session 1 for reading the Qur'an and session 2 for practicing worship. The details of the learning steps in session 1 are as follows:

- Instructor read one verse and repeats it three times

- One by one student reads the verse red by the instructor

- If there is a mistake, the instructor will correct it and clarify it directly

- After all students read one verse, the instructor asks them to read that verse in exercise menu in the e-BBQ where speech recognition is available for 30 minutes

The detailed steps of learning in session 2 are as follow:

- Students learn the topic of worship in the menu of worship education in the e-BBQ application

- Instructor firstly checks whether students' worship practice is correct or not

- The instructor gives an example by directly practicing to the students who incorrectly practice worship

- Students are asked to learn again in the menu of worship education in the e-BBQ application for reinforcement

- The instructor checks again whether the students' worship practices need to be corrected

Evaluation tools in this study include:

- The instrument for measuring the validity of m-LMS based on the expert judgment in the form of validation sheets for media, topics, and language experts

- Observation sheet of ability to perform worship (ablution, prayer, fasting, and almsgiving) and the ability to read the Qur'an to measure the extent of changes in the ability after the implementation of learning with m-LMS

- Semi-structured interview forms and design assessment questionnaires and the use of media to find out the responses and perceptions of students and instructors

Expert validation sheets and learning questionnaires using a Likert scale of 1-5 with the criteria of "very good (5), good (4), moderate (3), bad (2), very bad (1)". Meanwhile, the filled out observation sheet refers to the rubric that had been used in 
Islamic religious education courses, with the assessment components covering the procedures and provisions of worship that are permanent and cannot be changed.

\subsection{Develop}

Develop includes creating e-BBQ applications and website based on the blueprints produced at the design stage using software. This stage consists at least of the manufacturing and evaluation stages.

The application and writing of code in this development used the Front End application with XML, followed by writing the Java language program code using the IDE android 2.0 studio. The design and program units on the e-BBQ application and website that had been developed were then combined with other programs. The developed e-BBQ application (Figure 1) has four main menus (Figure 2), namely Reading Qur'an Learning, Worship Education, Exercise, and the Assessment for Instructors. This developed application focuses on improving students' ability to worship, especially ablution, prayer, almsgiving, and fasting. In the service, especially prayer, there is reading Qur'an. This activity requires a separated menu because reading the Qur'an has a fairly complicated rule called Tajweed.

The Reading Qur'an Learning menu has two submenus, namely Makharijul Letters and Learning Qur'an Verses. On the Makharijul letters menu, students can learn about the accuracy in reading per Hijaiyah letter. This menu facilitates students to pronounce Hijaiyah letters in accordance with the place where the voices come out. Meanwhile, on the Learning Qur'an Verses submenu, students are trained to read pieces of verses of the Qur'an. On this menu, there is a video and sound play button that will provide examples in reading Qur'an verses and a reading check button where students can practice reading verse clauses, and the application will provide feedback whether the reading is correct or not.

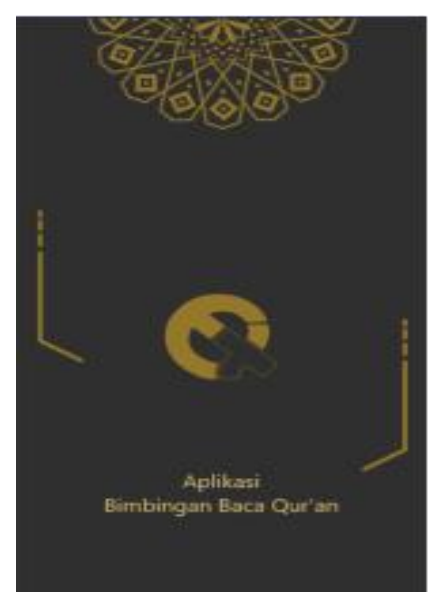

Fig. 1. Splash Screen

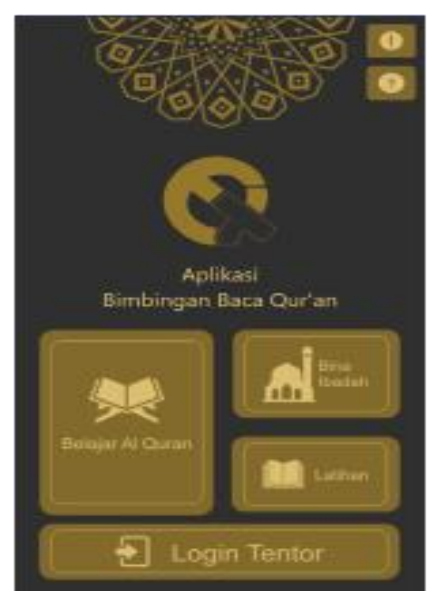

Fig. 2. Main Menu 
On the Worship Education menu, there are submenus of topic choices along with a brief introduction and topic submenu. This menu contains text, images, and videos about the components of worship including ablution, prayer, almsgiving, and fasting, especially reading, stages, and all the rules. The Exercise and Assessment menus are specific to the ability to read the Qur'an. From a number of worships that must be mastered by students, only the reading Qur'an that can be included in these two menus, while the ablution, prayer, almsgiving, and fasting must be done by practicing directly with specific movements so that the assessment is carried out through direct observation by the instructor, but giving the assessment still uses the application. The Exercise menu focuses on questions about the reading law by displaying a verse and asking the reading law or vice versa. Meanwhile, the Assessment menu is done by logging in first by the instructor, then entering the student's identities such as the student's master number, and this menu will appear in the apparatus which will be assessed accompanied by the plus (right) and minus (wrong) buttons. This assessment will be integrated with the scoring management website.

In addition to developing e-BBQ applications, this work also developed a website integrated with developed applications. All data are input from the e-BBQ application. In the website column, there are four main menus including a data management menu that contains student's data, a test report menu consisting of student's and instructor's reports, an e-BBQ account menu especially for instructors and managers, and a setting menu that contains the period and faculty directory settings. This website is focused on providing information on learning developments and is adapted to the university academic system.

The final step of this stage is testing to ensure the product complies with the specified specifications. System testing was divided into two, namely expert validation (material, media and language experts) and testing to users with one-to-one teaching method. Black-box testing techniques were also carried out by media experts to ensure that the product developed has good criteria from the aspect of software engineering. The validation stage was undertaken to consider assessments, criticisms, and suggestions from experts to produce e-BBQ products that are feasible and good to be applied in the learning of Islamic Religious Education, especially worship education. Validation was conducted by experts in three fields namely material, language, and media.

The material and language aspects of the product were validated by five experts. Material and media validation sheets given to experts consisted of 12 questions with several components including curriculum, content, and language. Validation from the aspect of media was carried out by five experts consisting of three fields of instructional media design and two fields of information technology. For information technology, the focus was more on black-box testing. The media validation sheet given to experts consisted of 14 questions with several components including visual communication and software engineering. The data validity in this study was analyzed by calculating percentages of the quantitative data. Products could be said to be feasible if the percentage of each aspect reached $80 \%-85 \%$ (good) and $>85 \%$ (very good) for validation by media and language experts, and $100 \%$ for validation by material experts, and 75-80 \% (good enough), 80\% -85\% (good), and $>85 \%$ (very good) for 
instructors and students [61]. To guarantee the reliability of the obtained data, the reliability of research results from all experts was calculated by using Cronbach alpha.

The results of validation by material and language experts and media experts it showed that the average percentage of validity from material and language experts was $96 \%$ and that from media experts was $97 \%$. Validity checking by information technology experts found a number of technical errors such as unworking navigation and content that did not appear in some menus. The development team had overcome this problem and the results had been re-examined by the experts and they declared that the product was feasible for use. The calculation of reliability between material and language expert judgment was 0.827 and media expert was 0.826 . These results indicated that the instruments used were reliable, and the quality of e-BBQ product developed was good. The information obtained from this validation stage showed that e-BBQ meets the quality of the material and language according to Elissavet \& Economides [62] and the media quality according to Arsyad [63] and Wahono [64].

A small-scale test on four students using the one-to-one teaching method was done by installing the e-BBQ application on a student's smartphone. Students followed the learning by using applications that had been developed, then at the end of the learning they were asked to fill out a questionnaire. Stages of trial with one-to-one teaching were to consider students' criticism and suggestions. These results were used to improve the quality of products developed and used in large-scale trials. The questionnaire given to students consisted of 12 questions covering software engineering, visual communication, content, and language. The small-scale trials resulted in $78 \%$ (pretty good). Meanwhile, the questionnaire given to the instructors consisted of 15 questions covering software engineering, visual communication, content, language, and curriculum. The average percentage of media eligibility based on instructor ratings was $87 \%$. The calculation results of reliability between student and instructor assessments were 0.753 and 0.905 . These results indicated that the instruments used were reliable and the products developed had excellent and decent quality. In addition, from these results it can be said that the media could be accepted and used by students and instructors, and in general, it can be used by instructors as a medium in teaching worship in Islamic Education courses at the higher education level.

\subsection{Implement}

The fourth stage, implement is the stage of teaching by using developed products. Teaching worship with e-BBQ including reading the Qur'an was conducted on 100 students who took Islamic Education courses with one instructor for each group of students (1 group consisted of 10 students). Thus, there were ten simple randomly selected groups of students. The product implementation was carried out at Universitas Negeri Malang in the odd semester of the 2018-2019 school year. The implementation was undertaken with one-group pretest-posttest design. Learning was carried out for sixteen weeks. In first-week, students were given a pretest once. The pretest was done by practicing directly in front of the instructor covering several worships, namely ablution, prayer, almsgiving, and fasting, including the ability to read the Qur'an. In the second to the fifteenth-weeks students were given learning by using the 
e-BBQ application that had been developed. In the sixteenth week, students were given a posttest with the same assessment as the pretest. In this last week, students and instructors were also asked to provide an assessment of the learning design and use of the e-BBQ application by filling out questionnaires and semi-structured interviews. Pretest and posttest used evaluation instruments that had been determined in the design stage. The learning design at this implementation stage is summarized in Table 1.

\subsection{Evaluate}

The fifth stage, evaluate, included all improvements to the e-BBQ application and website. The evaluation was divided into formative and summative evaluation throughout the design process. The formative and summative evaluations used quantitative and qualitative methods. The formative evaluation included evaluation of the results of expert validation and suggestions based on the obstacles faced by instructors and students during teaching, both with the one-to-one teaching method at the develop stage and classical teaching at the implementation stage. Whereas, summative evaluation was guided by the Kirkpatrick model [65] which includes four levels. In this study, we focused on the first two levels: level 1 - their opinion on e-BBQ learning through interviews at the end of the implementation stage, and level 2 - measuring how the product developed could help students improve their ability to practice worship through measurement of practical tests.

Table 1. The learning design at implementation stage

\begin{tabular}{|c|l|l|l|}
\hline Group & \multicolumn{1}{|c|}{ Pre-test } & \multicolumn{1}{|c|}{ Procedure } & \multicolumn{1}{c|}{ Post-test } \\
\cline { 2 - 4 } Students & $\begin{array}{l}\text { The practical test of the ability to } \\
\text { worship (ablution, prayer, fasting, } \\
\text { and almsgiving) }\end{array}$ & $\begin{array}{l}\text { Learning by using e- } \\
\text { BBQ }\end{array}$ & $\begin{array}{l}\text { The practical test of the ability to } \\
\text { worship (ablution, prayer, fasting, and } \\
\text { almsgiving) } \\
\text { Self-study learning questionnaire } \\
\text { Interview form }\end{array}$ \\
\hline Instructor & - & $\begin{array}{l}\text { Learning by using e- } \\
\text { BBQ }\end{array}$ & $\begin{array}{l}\text { Self-study learning questionnaire } \\
\text { Interview form }\end{array}$ \\
\hline
\end{tabular}

\subsection{Data analysis}

For summative evaluation of level 1- responses in the form of statements were processed by content analysis. This analysis was done by writing the data code individually obtained from interviews. The identities of the instructors and students interviewed were kept confidential and each person was numbered (Instructor 1: I1, Student 1: S1). Some categories were created after completing coding and then tabulated as frequencies supported by direct quotations from the students' and instructors' opinions. To ensure the reliability of the research data, the results of the coding were then submitted to some field experts for later verification of their validity. In addition, this study also calculated an occurrence agreement with the formula of "reliability = agreement / agreement + disagreement x 100." The calculation results showed that the 
score of the occurrence agreement $>75 \%$, meaning the data could be said to be quite reliable.

For summative evaluation 2- to find out the extent to which the increase in worship ability after the implementation of learning using e-BBQ, the data were analyzed using paired t-test. The improvement of ability is said to be significant if the $p$ value is less than 0.05. Before performing the paired t-test analysis, the pretest and posttest data were tested for classical assumptions to check the data normality. The data normality was calculated using Kolmogorov-Smirnov one sample.

\section{$3 \quad$ Findings}

\subsection{Formative evaluation}

Formative evaluation in this research and development using ADDIE was iterative for each stage. To make it easier in identifying how formative evaluation was carried out during this e-BBQ development research, we made a summary to illustrate the inputs and outputs of each phase in Table 2.

Table 2. Input and output of each phase in e-BBQ development

\begin{tabular}{|l|l|l|}
\hline ADDIE & \multicolumn{1}{|c|}{ Inputs } & \multicolumn{1}{|c|}{ Outputs } \\
\hline Analysis & $\begin{array}{l}\text { Results of observation on teaching problems } \\
\text { Results of the interview on students' responses } \\
\text { to learning process }\end{array}$ & $\begin{array}{l}\text { Need analysis data } \\
\text { Students' characteristics or conditions } \\
\text { Learning problems }\end{array}$ \\
\hline Design & $\begin{array}{l}\text { Students' needs in learning } \\
\text { Results of discussion on learning problems }\end{array}$ & $\begin{array}{l}\text { Design or components of e-BBQ } \\
\text { Goal and design of learning } \\
\text { Evaluation instruments }\end{array}$ \\
\hline \multirow{2}{*}{ Develop } & $\begin{array}{l}\text { Design of e-BBQ } \\
\text { Software of e-BBQ forming. } \\
\text { Validation sheet of e-BBQ }\end{array}$ & $\begin{array}{l}\text { Application and website of e-BBQ } \\
\text { Results of experts' validation } \\
\text { Results of trying out the one to one teaching }\end{array}$ \\
\hline Implement & $\begin{array}{l}\text { Design of implementation } \\
\text { Test and questionnaire }\end{array}$ & $\begin{array}{l}\text { Improvement of e-BBQ } \\
\text { Improvement of learning }\end{array}$ \\
\hline Evaluate & Summative evaluation & Results of evaluation level 1 and 2 \\
\hline
\end{tabular}

\subsection{Level 1-Summative evaluation - instructors' and students' opinions}

At the end of the lesson, interviews were conducted with the instructor regarding the characteristics and use of e-BBQ in teaching worship to students. The questions asked to the instructors also included advantages, disadvantages, and differences in eBBQ with multimedia in general. A summary of instructors' opinions on the use of eBBQ is shown in Table 3.

Based on the instructors' opinions in Table 3, they viewed that the quality of learning by using e-BBQ to teach worship, in general, is attractive because it combines some components or elements. They argued that the advantage of e-BBQ was the attractiveness of design so that it could make learning more fun and students did not feel bored while studying. Another advantage is that this e-BBQ application contains material that is relatively concise and accessible anytime by students. This flexibility 
has given a better offer in worship learning. Meanwhile, the weakness of e-BBQ lies in compatibility with Android with systems under 3.0 or having RAM less than $1 \mathrm{~GB}$. Finally, the difference between e-BBQ and other multimedia is that it can be used together with some other learning media in the classroom.

Table 3. Instructor's opinion of learning by using e-BBQ

\begin{tabular}{|l|l|c|}
\hline \multicolumn{1}{|c|}{ Category } & \multicolumn{1}{|c|}{ Theme } & f \\
\hline \multirow{4}{*}{ Defining and evaluating e-BBQ } & Attractive & 10 \\
\cline { 2 - 3 } & A good alternative & 8 \\
\cline { 2 - 3 } & Combining usage of several components & 5 \\
\hline \multirow{5}{*}{ Advantages of e-BBQ } & Creating fun and enjoyable learning & 10 \\
\cline { 2 - 3 } & Removing boredom and motivating & 10 \\
\cline { 2 - 3 } & Summarizing & 7 \\
\cline { 2 - 3 } & Playback of content every time & 6 \\
\hline \multirow{2}{*}{$\begin{array}{l}\text { Disadvantages and limitations } \\
\text { of e-BBQ }\end{array}$} & No limitation & 3 \\
\cline { 2 - 3 } & Distraction & 3 \\
\cline { 2 - 3 } $\begin{array}{l}\text { Differences of e-BBQ from } \\
\text { other multimedia }\end{array}$ & Technical problems & 6 \\
\cline { 2 - 3 } & Pombining usage of several components & 5 \\
\cline { 2 - 3 } & Presentation with visual and audio components & 5 \\
\hline
\end{tabular}

Following are some excerpts from the direct interview with the instructors. The underlined sentences are keywords included in the theme.

"As an instructor, I feel that the e-BBQ application is quite different from the existing multimedia generally used before, which visually has excellent quality in delivering material accurately, concisely, and clearly. With this advantage, e-BBQ is enough to make an interesting learning experience and make students able to understand the material better "I3

"After obtaining the final results of learning by using e-BBQ, I think that students could better understand what we were conveying in class, this is likely because eBBQ is sufficient to make students not feel bored and to create class more fun than just learning with lecture methods that tend to be verbal "I7

"I found no significant obstacles in learning by using e-BBQ, it is just my opinion learning in this way offers a promising alternative to learning. However, in my opinion, it can also create significant problems when learning begins; on the other hand, students have not installed it on a smartphone. This case needs to be considered because it will take more time, it should also be noted for students who do not have a supporting device or their devices do not support the application "I10

Interviews conducted to students only included their opinions after learning by using e-BBQ and what recommendations might be given for the continued development of e-BBQ in the future. A summary of students' opinions on learning with the e-BBQ application is shown in Table 4.

Based on the students' opinions in Table 4, the implementation of learning by using e-BBQ was very fun and made them enjoy the learning. They also felt that e-BBQ was an essential component in the learning of religious worship in Islamic religious 
education. The recommendation that was widely mentioned by students towards the further development of e-BBQ was to provide plenty of animations and videos to illustrate the practice of reading the Qur'an and worship.

Table 4. Students' opinions of learning by using e-BBQ

\begin{tabular}{|l|l|c|}
\hline \multicolumn{1}{|c|}{ Category } & \multicolumn{1}{c|}{ Theme } & f \\
\hline \multirow{4}{*}{$\begin{array}{l}\text { Students' opinion of the e-BBQ } \\
\text { application after implementation }\end{array}$} & Fun and enjoyable & 76 \\
\cline { 2 - 3 } & Interesting and motivating & 65 \\
\cline { 2 - 3 } & Support learning & 27 \\
\cline { 2 - 3 } & Simple and clear & 10 \\
\cline { 2 - 3 } Students' recommendations of the & Not bad & 56 \\
\hline \multirow{2}{*}{\begin{tabular}{l} 
e-BBQ application \\
\cline { 2 - 3 }
\end{tabular}} & Should be animated & 24 \\
\cline { 2 - 3 } & Should be more videos & 15 \\
\cline { 2 - 3 } & No recommendations & 56 \\
\hline
\end{tabular}

The following are excerpts of some direct quotations from interviews with students. The underlined sentences are keywords included in the theme.

"This e-BBQ application is very helpful for me, I often use a smartphone, wherever I go, I always carry it, so I think I will give more time for me to learn and understand the material, I like learning like this very much "S24

"I have previously learned about the same thing, but in this way it turned out to be very fun, I feel like learning again in this way, really, I feel motivated, but in the future this application may need to be designed more interestingly, for example, with animation" S65

"I think this application has been designed to be quite interesting, simple, and focused on the content being taught, I feel there is nothing important to add, but some problems in using a telephone device is a small screen and batteries that are often low sometimes" S88

In general, instructors and student opinions about the use of e-BBQ in religious teaching and learning were positive. The findings from frequency calculations, the views with the theme of fun and enjoyable (playfull) were higher than the benefits of this application in supporting learning activities such as increasing student's motivation and consistency with content and learning objectives. These results indicated that the attractiveness of e-BBQ in terms of interface design and appearance is still the main attraction of students and instructors' attention rather than the ease of use and usefulness of e-BBQ in the teaching and learning process. This result is also consistent with recommendations from students who stated that the developed media product still needs to add animation. This recommendation reinforces the notion that the principle of enjoyable in making $\mathrm{m}$-LMS becomes the main consideration.

The questionnaire used in the formative evaluation at the develop stage was reused to find out whether there was an increase in quality according to the assessment of students as users. The results showed that generally, the evaluation reached $80 \%$ (Table 5). There was an increase but insignificant compared to the previous one. From this result, e-BBQ, according to the student assessment, increased to a good category from the previous one which was in the moderate category. 
Table 5. Results of e-BBQ trial assays by students of large scale

\begin{tabular}{|l|c|c|l|}
\hline \multicolumn{1}{|c|}{ Aspects of Assesment } & Number of Items & Feasibility Percentage & \multicolumn{1}{c|}{ Criteria } \\
\hline Audio and visual display & $1,2,3,4$ & $80 \%$ & Good \\
\hline Software engineering & $5,6,7$ & $81 \%$ & Good \\
\hline Content learning & $8,9,10$ & $81 \%$ & Good \\
\hline Language style & 11,12 & $80 \%$ & Good \\
\hline Average & & $80 \%$ & Good \\
\hline
\end{tabular}

\subsection{Level 2-Summative evaluation- students' learning outcome}

Before testing the hypothesis, first, the normality test was done with the Kolmogorov-Smirnov one-sample test, the calculation results showed the value of $\mathrm{p}(0.575)>$ 0.05 , then the data were normally distributed. Based on the results of hypothesis testing with Paired-t-Test, the value of $t=18.802$ with a value of $p(0.000)<0.05$, meaning that there was a significant increase in the students' ability to worship after learning by using e-BBQ. According to these findings, the students' ability was initially quite sufficient (index letter $\mathrm{C}$ ) with a mean value $=55.97$ (Standard deviation $=$ 16.46) and increased to the mean $=82.64$ (Standard deviation $=7.85$ ) classified as good (index letter A) (Figure 3). When it is viewed from the smaller standard deviation, there was a narrowing of the capacity gap. Before implementation, namely the initial ability, there was a wide gap as explained in the analytical analysis, after the implementation of learning by using e-BBQ, the students' skill was more evenly distributed. Thus, it can be said that the use of e-BBQ in the learning of worship in Islamic education courses gave a positive impact on improving student's ability.

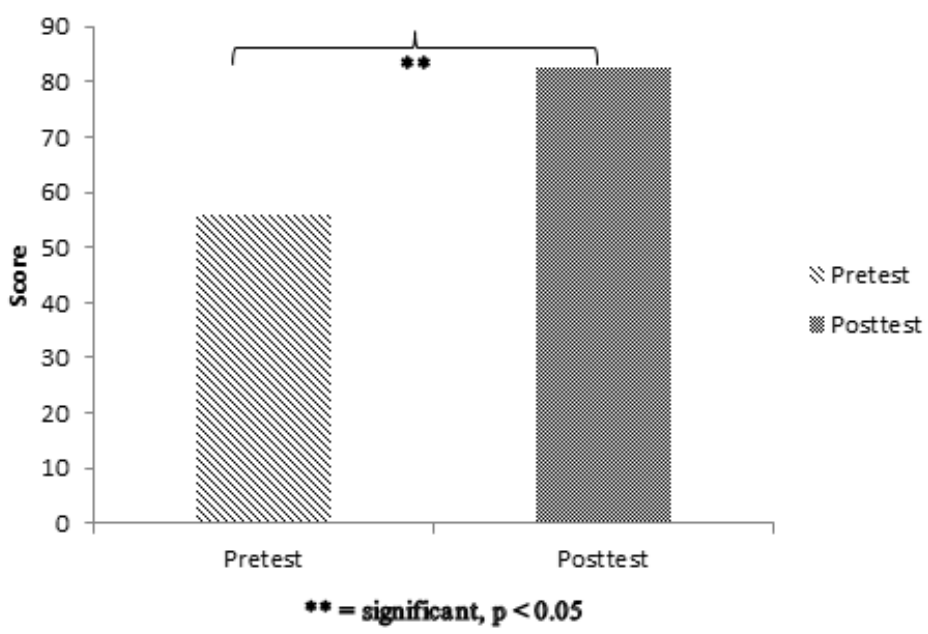

Fig. 3. Students' Learning Outcome 


\section{Discussion and Conclusion}

In this study, e-BBQ was developed to examine the impact of its use on learning outcomes in Islamic religious education courses. In addition, the opinions of students and instructors as end-users were evaluated. Through the application of the ADDIE model, e-BBQ was developed and evaluated in each phase. Level -summative evaluation results showed that students could accept the use of e-BBQ well and gave positive responses to the use of this application. They assessed that e-BBQ could support their learning to achieve learning goals more quickly. Also, the results from level 2- the use of e-BBQ could improve the students' ability to worship. This report has provided an initial basis that the m-LMS can be developed using ADDIE to provide supporting facilities in the process of religious worship learning in Islamic religious education courses in higher education effectively and efficiently. Many researchers like Han \& Shin [66], Hung, Lam, Wong, \& Chan [67], and Mohd Kasim \& Khalid [68] explained that m-LMS is one of the promising ways compared to traditional LMS in educational world, especially in improving students' learning outcome in universities. Therefore, this result is expected to be able to actively support all stakeholders to develop m-LMS in Islamic educational education that is now still limited.

From a series of evaluations at each phase during the development and implementation of e-BBQ, there were some lessons to be learned by researchers and instructors. In the analysis phase, studies to obtain learning needs data should not be limited to students with a data collection technique. In this phase, stakeholder involvement is needed, at least the instructor and experts are involved in providing input and assessment to obtain a more thorough and in-depth study. The study does not only explains whether the product that will be developed does not yet exist and is needed but also needs to examine the extent to which students' abilities are currently available and how the availability of learning support for the application of the product that will be developed. This study is essential so that students can access the products developed and prefer to use the product sustainably.

At the design stage, the determination of product components must be adjusted to the learning objectives. In this stage, learning objectives must be measured. This case is essential to maintain focus in evaluating product success. The most important principle in this phase, the development team must have excellent communication with the instructor so that the content in the product matches the strategy that will be implemented and the learning objectives. At the develop stage, although ADDIE does not explicitly explain the need for informatics engineering experts to examine engineering software in the development of learning platforms, we need to recommend to involve these experts so that products that are developed technically are not problematic and are suitable for use in the implementation phase. In addition, it also needs to be tested on a small scale on some students as end-users, for example with one to one teaching to review whether there are difficult things for students to use. At the implementation stage, we also recommend that students can reassess how the quality of the product. This information is vital for consideration in the final revision of the product, 
further development in the future, and anticipating obstacles that instructors might experience in using the product.

According to the conclusions from the evaluation results of the instructors' opinions, it can be seen that in general, they were positive. The results in this study are in line with the study conducted by Teri et al. [69] and Papadakis [70] reporting that the application of mobile learning could foster students' positive attitudes and perceptions in terms of adopting and using the technology for educational purposes. In research conducted by Yildiz, Tezer, and Uzunboylu [71], it was found that students had positive opinions on LMS in the online learning system in higher education. They consider that e-BBQ could attract the students' attention. Also, the e-BBQ is believed to be alternative learning that can be integrated into learning strategies. When the students were asked about excellence, they also thought that e-BBQ could create fun learning and eliminate boredom. They also ensured that e-BBQ could present a summary of learning material effectively, as well as presentation with learning videos that could visualize the procedures for worship in Islamic religion completely and could be played repeatedly.

In this study, students' opinions were also evaluated after students used the e-BBQ application. They stated that this application could create fun learning. They were highly more motivated to learn. They thought that e-BBQ could present suitable content in a concise and clear manner. Miao [72] and Alnabhan \& Aljaraideh [73] explained that mobile learning has an interactive design that could stimulate students to have higher learning motivation and attract students' attention. Other studies, Wang, $\mathrm{Wu}, \&$ Wang [16] also showed that mobile learning could make learning more fun and attract more users. As with mobile learning, there are also findings that LMS could motivate users and make learning more fun [74].

The instructors' and students' positive responses to the use of e-BBQ gave encouraging results. Some studies have shown that instructor's positive attitude is very influential on the quality of learning and student's learning outcomes. Research conducted by Ulug, Ozden, \& Eryilmaz [75] showed that teacher's positive attitude had a positive effect on student's performance and vice versa. It is further explained that students take role models while learning and that is why the teacher's positive attitude towards learning undertaken needs to be maintained continuously. In the context of technology integration in learning, the teacher's positive attitude towards technology is a critical condition so that technology can be applied in learning well [76]. From this opinion, it can be concluded that the instructor's positive attitude towards the use of e-BBQ has also created a positive attitude towards students, it can be seen that there are similar opinions that e-BBQ can help learning to be more fun and motivating. Praise that is given by instructors and students also strengthens the opportunity of transitioning from traditional learning methods to be more student-centered by using e-BBQ.

There are some factors that influence students in using technology. According to the results of research as in the framework of the Technology Acceptance Model (TAM), the ease and usefulness of technology are the main predictors in technology selection [36] [72] [78]. From the interview results, this factor was also expressed by students after participating in learning by using e-BBQ. Nevertheless, it seemed that 
students were more interested because of playful factors (enjoyable and fun). Venkatesh, Thong, \& Xu [79], Fagan [80], and Huang, Wang, Tang, Chen, \& Yu [81] explained that playfull could significantly influence the interest in using technology. In addition, from the students' statement, it can be assumed that the past experience factors and habits of using smartphones in daily life also affected the use of e-BBQ, as explained by Abas, Peng, \& Mansor [82] and Venkatesh et al. [79].

Seeing the results of the interview related to the weaknesses of the use of e-BBQ, instructors and students complained more about technical issues regarding the device. This case is a permanent weakness of mobile learning as explained by Alomary, Woollard, \& Evans [83] and Bhardwaj \& Jain [32]. Issues regarding the small screen were also encountered in research conducted by Nawi, Hamzah, Ren, \& Tamuri [20]. Their study found an assumption that mobile learning is "inappropriate" to be used for senior teachers because of the small screen. Reports on this limitation were also found in research conducted by Saefi et al. [84]. Cheon, Lee, Crooks, \& Song [85] explained that this problem is indeed common because users usually access devices with different processor sizes and speeds, the most important thing is the design of the interface and content according to user needs. In the context of e-BBQ, users are advised to use a device with a minimum screen size of 6 inches with a system above 3.0 and 1 GB RAM to avoid some technical obstacles. Regarding how to use it, this e-BBQ can be used independently or as part of classroom learning activities such as the implementation stage of this research.

Apart from weaknesses as the characteristics of the use of smartphone devices, the development of e-BBQ was designed to offer a new experience in learning Islamic religion by presenting an effective feature namely the login of instructor menu. This menu provides facilities for students to get constructive feedback from their instructors quickly. It is important to remember that learning management problems are also still faced. Learning in worship learning is conducted in small groups with a maximum of 10 students so that the learning needs a lot of instructors. Equalizing assessment perceptions among instructors and providing timely, integrated feedback to thousands of students within 24 hours, is not an easy task. One of the benefits of eBBQ is that it makes instructors easily carry out this task. The findings of this study are also in line with Sorensen's opinion [86] explaining that feedback is an integral part of the e-learning environment. In mobile learning, the role of instructors and students changes, where students can evaluate their learning progress independently, while instructors can provide evaluations quickly and simply [87]. In addition, online rubrics such as e-BBQ can provide many advantages to instructors namely a simpler assessment process and a shorter time [88]. The form of providing timely and efficient feedback to students can also encourage active learning. Afify [89] explained that the effectiveness of e-learning can be improved by providing direct feedback that can encourage students to gain more learning experiences. Given the positive impact of the instructor log-in menu, we recommend that application developers, especially for Islamic education learning, should add this facility to their learning platforms.

In general, the results of this level 1 summative evaluation provided a report that the use of e-BBQ had a positive impact on religious learning, where students had more motivation to learn. Students who were highly motivated to engage in learning 
using e-BBQ may be able to show changes in abilities. Some research reported that higher learning motivation will affect higher learning outcomes [77]-[79].

Contra to this report, Golenhofen et al. [93] found that in mobile learning, better motivation was not matched by better learning outcomes. Thus, an evaluation of the effectiveness of e-BBQ on learning outcomes was also carried out.

Summative 2- evaluation results conclusively found that e-BBQ effectively improved students' learning outcomes. Research on learning platforms, both mobile learning and LMS has been widely carried out and its effectiveness in improving student learning outcomes in various fields of science and education level has been proven. Research conducted by Gezgin [94], Males, Bate, \& Macnish [95], Saefi, Lukiati, \& Suarsini [84], Rashid, Salleh, \& Noor [96], and Elfeky \& Yakoub Masadeh [97] confirmed that mobile learning could improve students' learning outcomes. Previous research also revealed that mobile learning has the potential to be developed in supporting Islamic religious learning as reported Nawi \& Hamzah [98] and Abdullah \& Siraj [99].

Notwithstanding these results, there are reports that student learning outcomes could not be improved by mobile learning, and even tend to be the same as ordinary learning as reported by Miller \& Cuevas [100] and Xue, Zhang, \& Luo [101]. As explained in the design phase, the results were less satisfactory from the use of mobile learning because of the lack of students and instructors' involvement. With this result, it can be said that the addition of the login of instructor facility is quite significant in supporting learning success, although further exploration needs to be done to ensure this.

The effectiveness of LMS in improving learning outcome has been proven. Research conducted by Kim [102] showed that there was a relationship between the use of LMS and academic performance positively and strongly. Nair \& Patil [103] also reported that the use of LMS had facilitated students to improve skills and retention. The analysis results of LMS feature by Kulshrestha \& Kant [104] showed that LMS feature could help students to achieve academic advantage compared to using traditional learning.

This research reported that the development of e-BBQ applications is one part of efforts to strengthen the learning of more modern Islamic religion in Indonesian higher education. It should be realized that the implementation of the e-BBQ application does not carry out a very rigorous evaluation. The limitations of this study include the inability to assess pre- and post-implementation capabilities using standardized assessments. The assessment was carried out by the observation that could provide a biased assessment because there could be different perceptions between instructors. However, in this study, some efforts have been made to measure the ability of more than three instructors so that the data obtained were more accurate and could minimize the data bias. The sample in this study was also still relatively narrow and included one university. In addition, we have not been able to assess the success of eBBQ implementation at levels 3 and 4 according to the Kirkpatrick model.

Based on the results found, it can be concluded that the e-BBQ could be applied effectively in the teaching of Islamic religions, and this platform has high potential to be adapted in supporting and reinforcing the more modern Islamic religious learning. It 
can be recommended that the e-BBQ should be used in religious formation. For the same results, it is recommended that the development of similar learning platforms should be designed to attract and strengthen the instructor's involvement. Instructors also need training in developing this platform so they can provide more dynamic learning material. This research also provides information on the development of a learning platform similar to e-BBQ that can be carried out within the ADDIE IDM framework to enhance and support the success of learning the Islamic religion efficiently and effectively.

This research was conducted in a public university environment. Future similar studies may include Islamic tertiary institutions so that the effectiveness of using this platform can be evaluated in a broad sample of different educational backgrounds. Future studies can also be in the form of experimental studies comparing students using e-BBQ with students using other similar applications. Thus, the impact of eBBQ can be examined more deeply. To obtain students' perceptions of the use of eBBQ more measurable, in the future, studies need to be conducted to validate how predictors of perceived to be useful and perceived easy to use significantly influence behavior intention on e-BBQ.

\section{Acknowledgement}

This work was supported by PNBP research grant of Universitas Negeri Malang under contract No: 26.3.28/UN32.14.1/2019. We appreciate the Al-Qur'an Study Club (ASC) Universitas Negeri Malang that participated in data collection. We also express our gratitude to all participants who gave an opinion of e-BBQ.

\section{References}

[1] M. M. A. Sholeh, "Symbolism In Shalat (Prayer): A Conceptual Study on Shalat as The Method of Islamic Education,” Int. J. Islam. Civilizational Stud., vol. 01, no. 1, pp. 88-97, 2017. https://doi.org/10.11113/umran2017.4n1-1.208

[2] Z. Razak et al., "Quranic Verse Recitation Recognition Module for Support in j-QAF Learning: A Review," IJCSNS Int. J. Comput. Sci. Netw. Secur., vol. 8, no. 8, pp. 207216, 2008.

[3] W. M. Muhammad, R. Muhammad, A. Muhammad, and A. M. Martinez-Enriquez, "Voice Content Matching System for Quran Readers," in 2010 Ninth Mexican International Conference on Artificial Intelligence, Pachuca, Mexico, 2010, pp. 148-153. https://doi.org/10.1109/micai.2010.11

[4] C. Alba, "Studi Aktivitas Masjid Kampus dan Pembinaan Imtaq Bagi Mahasiswa Perguruan Tinggi Umum," J. Sosioteknologi, vol. 22, no. 10, pp. 1022-1042, 2011.

[5] A. Marini, D. Safitri, and I. Muda, "Managing School Based on Character Building in The Context of Religious School Culture (Case in Indonesia)," J. Soc. Stud. Educ. Res., vol. 9, no. 4, pp. 274-294, 2018.

[6] A. Asyafah, "The Method of Tadabur Qur'an: What Are the Student Views?," Int. Educ. Stud., vol. 7, no. 6, pp. 98-105, May 2014. 
[7] M. Zuhdi, "Challenging Moderate Muslims: Indonesia's Muslim Schools in the Midst of Religious Conservatism,” Religions, vol. 9, no. 10, pp. 1-15, 2018. https://doi.org/10.3390/rel9100310.

[8] M. Menekse, S. Anwar, and S. Purzer, "Self-Efficacy and Mobile Learning Technologies: A Case Study of CourseMIRROR," in Self-Efficacy in Instructional Technology Contexts, C. B. Hodges, Ed. Cham: Springer International Publishing, 2018, pp. 57-74. https://doi.org/10.1007/978-3-319-99858-9_4

[9] M. A. Lubis, M. Yunus, M. Diao, T. Arifin, R. Mustapha, and N. M. Ishak, "The Perception and Method in Teaching and Learning Islamic Education," vol. 5, no. 1, pp. 69-78, 2011.

[10] M. N. S. Syah, "Challenges of Islamic Education In Muslim World: Historical, Political, and Socio-Cultural Perspective," QIJIS Qudus Int. J. Islam. Stud., vol. 4, no. 1, pp. 82$105,2016$.

[11] I. N. Hidayat, "Pengaruh Teknik Repeated Reading terhadap Kemampuan Reading Fluency pada Siswa Kelas III Sekolah Dasar," Psympathic J. Ilm. Psikol., vol. 6, no. 1, pp. 766775, Feb. 2018. https://doi.org/10.15575/psy.v6i1.2134

[12] A. Göl, "Constructing knowledge: An effective use of educational technology for teaching Islamic studies in the UK," Educ. Inf. Technol., vol. 17, no. 4, pp. 399-416, Dec. 2012. https://doi.org/10.1007/s10639-011-9165-9

[13] M. Z. M. Zin, A. A. Sakat, N. A. Ahmad, and A. Bhari, "Relationship Between the Multimedia Technology and Education in Improving Learning Quality," Procedia - Soc. Behav. Sci., vol. 90, pp. 351-355, Oct. 2013. https://doi.org/10.1016/j.sbspro.2013.07.102

[14] J. Black and L. W. Hawkes, "A Prototype Interface for Collaborative Mobile Learning," in Proceedings of the International Conference on Wireless Communications and Mobile Computing, Vancouver, British Columbia, Canada, 2006, pp. 1277-1282.

[15] L. Liu, L. Zhang, P. Ye, and Q. Liu, "Influence Factors of Satisfaction with Mobile Learning APP: An Empirical Analysis of China,” Int. J. Emerg. Technol. Learn. IJET, vol. 13, no. 03, pp. 87-99, 2018. https://doi.org/10.3991/ijet.v13i03.8381

[16] Y.-S. Wang, M.-C. Wu, and H.-Y. Wang, "Investigating the determinants and age and gender differences in the acceptance of mobile learning," Br. J. Educ. Technol., vol. 40, no. 1, pp. 92-118, 2009. https://doi.org/10.1111/j.1467-8535.2007.00809.x

[17] R. N. Patil et al., "Attitudes and Perceptions of Medical Undergraduates Towards Mobile Learning (M-learning),” J Clin Diagn Res, vol. 10, no. 10, pp. JC06-JC10, 2016.

[18] M. L. Crescente and D. Lee, "Critical issues of m-learning: design models, adoption processes, and future trends,” J. Chin. Inst. Ind. Eng., vol. 28, no. 2, pp. 111-123, 2011.

[19] G. Dunleavy, C. K. Nikolaou, S. Nifakos, R. Atun, G. C. Y. Law, and L. Tudor Car, "Mobile Digital Education for Health Professions: Systematic Review and Meta-Analysis by the Digital Health Education Collaboration," J. Med. Internet Res., vol. 21, no. 2, p. e12937, Feb. 2019. https://doi.org/10.2196/preprints.12937

[20] A. Nawi, M. I. Hamzah, C. C. Ren, and A. H. Tamuri, "Adoption of Mobile Technology for Teaching Preparation in Improving Teaching Quality of Teachers,” Int. J. Instr., vol. 8, no. 2, pp. 113-124, 2015.

[21] X. Zhang and J. Bi, "Design of a College English Mobile Learning System Based on CAD Model,” Int. J. Emerg. Technol. Learn. IJET, vol. 13, no. 04, pp. 139-149, 2018. https://doi.org/10.3991/ijet.v13i04.8477

[22] G.-J. Hwang and C.-C. Tsai, "Research trends in mobile and ubiquitous learning: a review of publications in selected journals from 2001 to 2010: Colloquium," Br. J. Educ. Technol., vol. 42, no. 4, pp. E65-E70, Jul. 2011. https://doi.org/10.1111/j.1467$\underline{8535.2011 .01183 . x}$ 
[23] M. Kalogiannakis and S. Papadakis, "Combining mobile technologies in environmental education: a Greek case study,” Int. J. Mob. Learn. Organ., vol. 11, no. 2, pp. 108-130, 2017. https://doi.org/10.24176/re.v8i1.1792

[24] N. Ibrahim and I. Ishartiwi, "Pengembangan Media Pembelajaran Mobile Learning Berbasis Android Mata Pelajaran IPA untuk Siswa SMP," Refleksi Edukatika J. Ilm. Kependidikan, vol. 8, no. 1, pp. 80-88, 2017.

[25] M. R. L. Alhafidz and A. Haryono, "Pengembangan Mobile Learning Berbasis Android sebagai Media Pembelajaran Ekonomi," J. Pendidik. Ekon., vol. 11, no. 2, pp. 118-124, 2018.

[26] F. Sholihah, "Pengembangan Mobile Learning Matematika Berbasis Android untuk Meningkatkan Kemampuan Pemahaman Matematis Siswa: Penelitian dan Pengembangan di SMA Negeri 24 Bandung," diploma, UIN Sunan Gunung Djati Bandung, Bandung, 2018. https://doi.org/10.21009/1.02104

[27] H. Anggraini, H. Novianti, and A. Bardadi, "Pengembangan Bahan Ajar Berbasis Android untuk Meningkatkan Kemampuan Pengucapan Pada Mahasiswa," J. Comput. Eng. Syst. Sci., vol. 3, no. 1, pp. 83-86, 2018. https://doi.org/10.31227/osf.io/f9a3w

[28] M. Zakariah, M. K. Khan, O. Tayan, and K. Salah, "Digital Quran Computing: Review, Classification, and Trend Analysis," Arab. J. Sci. Eng., vol. 42, no. 8, pp. 3077-3102, Aug. 2017. https://doi.org/10.1007/s13369-017-2415-4

[29] M. Sharples, I. Arnedillo-Sánchez, M. Milrad, and G. Vavoula, "Mobile Learning," in Technology-Enhanced Learning: Principles and Products, N. Balacheff, S. Ludvigsen, T. de Jong, A. Lazonder, and S. Barnes, Eds. Dordrecht: Springer Netherlands, 2009, pp. 233-249. https://doi.org/10.1007/978-1-4020-9827-7_14

[30] J. Gikas and M. M. Grant, "Mobile Computing Devices in Higher Education: Student Perspectives on Learning with Cellphones, Smartphones \& Social Media," Internet High. Educ., vol. 19, 2013. https://doi.org/10.1016/j.iheduc.2013.06.002

[31] O. Boyinbode and D. Ng'ambi, "MOBILect: an interactive mobile lecturing tool for fostering deep learning," Int. J. Mob. Learn. Organ., vol. 9, no. 2, pp. 182-200, 2015. https://doi. org/10.1504/ijmlo.2015.070706

[32] R. K. Bhardwaj and P. K. Jain, "Research trends in mobile learning: A global perspective," Collnet J. Scientometr. Inf. Manag., vol. 9, no. 2, pp. 205-224, Jul. 2015.

[33] V. P. Dennen and S. Hao, "Intentionally mobile pedagogy: the MCOPE framework for mobile learning in higher education," Technol. Pedagogy Educ., vol. 23, no. 3, pp. 397419, 2014. https://doi.org/10.1080/1475939x.2014.943278

[34] G.-J. Hwang, T.-C. Yang, C.-C. Tsai, and S. J. H. Yang, "A context-aware ubiquitous learning environment for conducting complex science experiments," Comput. Educ., vol. 53, no. 2, pp. 402-413, Sep. 2009. https://doi.org/10.1016/j.compedu.2009.02.016

[35] A. I. Saroia and S. Gao, "Investigating University Students' Intention to Use Mobile Learning Management Systems in Sweden," Innov. Educ. Teach. Int., pp. 1-12, Dec. 2018.

[36] S. Hao, M. Cui, and V. P. Dennen, "Analysis of mobile learning as an innovation in higher education: a comparative study of three countries," Int J Mob. Learn. Organ., vol. 11, no. 4, pp. 314-339, 2017.

[37] J. Abramson, M. Dawson, and J. Stevens, "An Examination of the Prior Use of E-Learning Within an Extended Technology Acceptance Model and the Factors That Influence the Behavioral Intention of Users to Use M-Learning," SAGE Open, vol. 5, no. 4, pp. 1-9, Dec. 2015. https://doi.org/10.1177/2158244015621114

[38] S. Papadakis, M. Kalogiannakis, E. Sifaki, and N. Vidakis, "Access Moodle Using Smart Mobile Phones. A Case Study in a Greek University," in Interactivity, Game Creation, De- 
sign, Learning, and Innovation, vol. 229, A. L. Brooks, E. Brooks, and N. Vidakis, Eds. Cham: Springer International Publishing, 2018, pp. 376-385. https://doi.org/10.1007/9783-319-76908-0_36

[39] S. Papadakis and M. Kalogiannakis, "Mobile educational applications for children: what educators and parents need to know," Int. J. Mob. Learn. Organ, vol. 11, no. 3, pp. 256277, 2017. https://doi.org/10.1504/ijmlo.2017.085338

[40] S. Papadakis, M. Kalogiannakis, and N. Zaranis, "Educational apps from the Android Google Play for Greek preschoolers: A systematic review," Comput. Educ., vol. 116, pp. 139-160, Jan. 2018. https://doi.org/10.1016/j.compedu.2017.09.007

[41] M. Kalogiannakis and S. Papadakis, "An Evaluation of Greek Educational Android Apps for Pre-Schoolers," in Electronic Proceedings of the ESERA 2017 Conference., Dublin, Ireland, 2018, vol. Research, Practice and Collaboration in Science Education, Part 4/Strand 4, pp. 593-603.

[42] N. Saad and S. Busrowi, "Barriers to Technology Integration in Islamic Education: An Insight of Excellent teachers," in Proceedings: New Directions In MultiDisciplinary Research \& Practice, Istanbul, Turkey, 2015, pp. 1-14.

[43] M. A. C. Noh and R. A. Tarmizi, "Persepsi Pelajar Terhadap Amalan Pengajaran Tilawah Al-Quran,” J. Pendidik. Malays., vol. 34, no. 1, pp. 93-109, 2009.

[44] S. J. Samuels, "The Method of Repeated Readings," Read. Teach, vol. 50, no. 5, pp. 376381, 1997.

[45] T. S. A. T. Kasim and Y. M. Yusoff, "Active Teaching Methods: Personal Experience of Integrating Spiritual and Moral Values," Relig. Educ., vol. 109, no. 5, pp. 554-570, Oct. 2014. https://doi.org/10.1080/00344087.2014.956560

[46] I. S. Wekke and M. A. Lubis, "Educational technology on teaching and learning of integrated islamic education in Brunei Darussalam," ULUMUNA, vol. 15, no. 1, pp. 185-204, Jun. 2011. https://doi.org/10.20414/ujis.v15i1.215

[47] Ishomuddin and S. B. Mokhtar, "Teaching-Learning Model of Islamic Education at Madrasah Based on Mosque in Singapore," Int. J. Asian Soc. Sci., vol. 7, no. 3, pp. 218-225, 2017. https://doi.org/10.18488/journal.1/2017.7.3/1.3.218.225

[48] M. Aziz, W. M. Abdullah, A. M. Ahmad, M. A. A. Mushim, and M. S. Shahrudin, "Comparison between Conventional Method and Modern Technology in Al-Qur'an Memorization,” Int. J. Recent Technol. Eng., vol. 8, no. 1, pp. 289-294, 2019.

[49] R. M. Branch, Instructional design: the ADDIE approach. New York: Springer, 2009.

[50] T. Trust and E. Pektas, "Using the ADDIE Model and Universal Design for Learning Principles to Develop an Open Online Course for Teacher Professional Development," J. Digit. Learn. Teach. Educ., vol. 34, no. 4, pp. 219-233, Oct. 2018. https://doi.org/10.1080/21 $\underline{532974.2018 .1494521}$

[51] C. Peterson, "Bringing ADDIE to Life: Instructional Design at Its Best," J1 Educ. Multimed. Hypermedia, vol. 12, no. 3, pp. 227-241, 2003.

[52] F. Giannakas, A. Papasalouros, G. Kambourakis, and S. Gritzalis, "A comprehensive cybersecurity learning platform for elementary education," Inf. Secur. J. Glob. Perspect., vol. 28, no. 3, pp. 81-106, May 2019. https://doi.org/10.1080/19393555.2019.1657527

[53] Y. Ishikawa, C. Smith, M. Kondo, I. Akano, K. Maher, and N. Wada, "Development and Use of an EFL Reading Practice Application for an Android Tablet Computer:," Int. J. Mob. Blended Learn., vol. 6, no. 3, pp. 35-51, Jul. 2014. https://doi.org/10.40 18/ijmbl.2014070103

[54] S. R. Patel, P. J. Margolies, N. H. Covell, C. Lipscomb, and L. B. Dixon, "Using Instructional Design, Analyze, Design, Develop, Implement, and Evaluate, to Develop e-Learning Modules to Disseminate Supported Employment for Community Behavioral Health 
Treatment Programs in New York State," Front. Public Health, vol. 6, p. 113, May 2018. https://doi.org/10.3389/fpubh.2018.00113

[55] W. Abouelsaadat, "Electronic Prayer Rug: Design and Evaluation," University of Toronto, Canada, 2012.

[56] S. Sotar, S. Suardinata, and R. S. Irawan, "Multimedia Learning Design for Ablution and Prayer (Case Studies at Pesantren Arafah Kota Sungai Penuh),” Int. J. Eng. Comput. Sci., vol. 7, no. 04, pp. 23827-23839, 2018. https://doi.org/10.18535/ijecs/v7i4.06

[57] S. Chomariyah, F. Fakhruddin, and S. Supriyadi, "Development of Interactive Multimedia on Ablution and Prayer Learning to Introduce Religious and Moral Values for Kindergarten," J. Prim. Educ., vol. 8, no. 3, pp. 270-280, 2019.

[58] N. Hamzah, N. D. Abd Halim, M. H. Hassan, and A. Ariffin, "Android Application for Children to Learn Basic Solat,” Int. J. Interact. Mob. Technol. IJIM, vol. 13, no. 07, p. 69, 2019. https://doi.org/10.3991/ijim.v13i07.10758

[59] M. A. M. Nawi, E. A. Jamsari, M. I. Hamzah, A. Sulaiman, and A. Umar, "The Impact of Globalization on Current Islamic Education,” Aust. J. Basic Appl. Sci., vol. 6, no. 8, pp. 74-78, 2012.

[60] M. Alqahtani and H. Mohammad, "Mobile Applications' Impact on Student Performance and Satisfaction," Turk. Online J. Educ. Technol., vol. 14, no. 4, pp. 102-112, 2015.

[61] G. Akbar, "Metode Pembelajaran Al-Qur'an melalui Media Online," Indones. J. Netw. Secur. IJNS, vol. 2, no. 1, pp. 65-68, 2013.

[62] G. Elissavet and A. A. Economides, "Evaluation Factors of Educational Software (Onway)," in Proceedings International Workshop on Advanced Learning Technologies (IWALT), California, 2000, pp. 113-120. https://doi.org/10.1109/iwalt.2000.890581

[63] A. Arsyad, Media Pembelajaran. Jakarta: Raja Grafindo Persada, 2013.

[64] R. S. Wahono, "Aspek dan Kriteria Penilaian Media Pembelajaran," Aspek dan Kriteria Penilaian Media Pembelajaran, 2006. [Online]. Available: http://romisatriawahono.net/2006/06/21/aspekdan-kriteria-penilaian-media-pembelajaran/. [Accessed: 21-Feb-2019]. https://doi.org/10.21009/jep.022.06

[65] D. L. Kirkpatrick, Evaluating training programs: the four levels, 1st ed. San Francisco: Emeryville, CA: Berrett-Koehler; Publishers Group West [distributor], 1994. https://doi.org/10.1016/s1098-2140(99)80206-9

[66] I. Han and W. S. Shin, "The Use of a Mobile Learning Management System and Academic Achievement of Online Students," Comput. Educ., vol. 102, pp. 79-89, 2016.

[67] P. Hung, J. Lam, C. Wong, and T. Chan, "A Study on Using Learning Management System with Mobile App," in 2015 International Symposium on Educational Technology (ISET), Wuhan, China, 2015, pp. 168-172. https://doi.org/10.1109/iset.2015.41

[68] N. N. Mohd Kasim and F. Khalid, "Choosing the Right Learning Management System (LMS) for the Higher Education Institution Context: A Systematic Review,” Int. J. Emerg. Technol. Learn. IJET, vol. 11, no. 06, pp. 55-61, 2016. https://doi.org/10.3 991/ijet.v11i06.5644

[69] S. Teri, A. Acai, D. Griffith, Q. Mahmoud, D. W. L. Ma, and G. Newton, "Student use and pedagogical impact of a mobile learning application: Mobile Learning Application," Biochem. Mol. Biol. Educ., vol. 42, no. 2, pp. 121-135, Mar. 2014. https://doi.org/10.1 002/bmb.20771

[70] S. Papadakis, "Evaluating pre-service teachers' acceptance of mobile devices with regards to their age and gender: a case study in Greece," Int. J. Mob. Learn. Organ., vol. 12, no. 4, pp. 336-352, 2018. https://doi.org/10.1504/ijmlo.2018.095130

[71] E. P. Yildiz, M. Tezer, and H. Uzunboylu, "Student Opinion Scale Related to Moodle LMS in an Online Learning Environment: Validity and Reliability Study," Int. J. Interact. 
Mob. Technol. IJIM, vol. 12, no. 4, pp. 97-108, Aug. 2018. https://doi.org/10.39 91/ijim.v12i4.9205

[72] G. Miao, "Interactive Design and Realization of Mobile Learning Resources through 3G Mobile Phones," in 2012 International Conference on Information Management, Innovation Management and Industrial Engineering, Sanya, China, 2012, pp. 56-59. https://doi.org/10.1109/iciii.2012.6339731

[73] M. Alnabhan and Y. Aljaraideh, "Collaborative M-Learning Adoption Model: A Case Study for Jordan,” Int. J. Emerg. Technol. Learn. IJET, vol. 9, no. 8, pp. 4-10, May 2014. https://doi.org/10.3991/ijet.v9i8.3639

[74] S. Wichadee, "Students' Learning Behavior, Motivation and Critical Thinking in Learning Management Systems," J. Educ. Online, vol. 11, no. 3, pp. 1-21, 2014. https://doi.org/10.9743/jeo.2014.3.3

[75] M. Ulug, M. S. Ozden, and A. Eryilmaz, "The Effects of Teachers' Attitudes on Students' Personality and Performance," Procedia - Soc. Behav. Sci., vol. 30, pp. 738-742, 2011. https://doi.org/10.1016/j.sbspro.2011.10.144

[76] T. Enayati, Y. Modanloo, and F. S. M. Kazemi, "Teachers' Attitudes towards the Use of Technology in Education,” J. Basic Appl. Sci. Res., vol. 2, no. 11, pp. 10958-10963, 2012.

[77] G. W.-H. Tan, K.-B. Ooi, J.-J. Sim, and K. Phusavat, "Determinants of Mobile Learning Adoption: An Empirical Analysis," J. Comput. Inf. Syst., pp. 82-91, 2012.

[78] M. Kalogiannakis and S. Papadakis, "Evaluating pre-service kindergarten teachers' intention to adopt and use tablets into teaching practice for natural sciences," Int. J. Mob. Learn. Organ., vol. 13, no. 1, pp. 113-127, 2019. https://doi.org/10.1504/ijmlo.2019.10016617

[79] V. Venkatesh, J. J. L. Thong, and X. Xu, "Consumer Acceptance and Use of Information Technology: Extending the Unified Theory of Acceptance and Use of Technology," MIS Q., vol. 36, no. 1, pp. 157-178, 2012. https://doi.org/10.2307/41410412

[80] M. H. Fagan, "Factors Influencing Student Acceptance of Mobile Learning in Higher Education," Comput. Sch., vol. 36, no. 2, pp. 105-121, Apr. 2019.

[81] C.-H. Huang, T.-F. Wang, F.-I. Tang, I.-J. Chen, and S. Yu, "Development and validation of a Quality of Life Scale for elementary school students," Int. J. Clin. Health Psychol., vol. 17, no. 2, pp. 180-191, 2017.

[82] Z. W. Abas, C. L. Peng, and N. Mansor, "A Study On Learner Readiness For Mobile Learning At Open University Malaysia," in IADIS International Conference Mobile Learning, Barcelona, Spain, 2009, pp. 151-157.

[83] A. Alomary, J. Woollard, and C. Evans, "To Use or Not Use: Mobile Learning?," in Proceedings of Academics World 27th International Conference, Paris, France, 2016, pp. 3235 .

[84] M. Saefi, B. Lukiati, and E. Suarsini, "Developing Android-Based Mobile Learning On Cell Structure And Functions Lesson Subject Topic To Optimize Grade XI Students' Cognitive Comprehension,” J. Pendidik. Sains, vol. 5, no. 2, pp. 57-63, 2017.

[85] J. Cheon, S. Lee, S. M. Crooks, and J. Song, "An investigation of mobile learning readiness in higher education based on the theory of planned behavior," Comput. Educ., vol. 59, no. 3, pp. 1054-1064, Nov. 2012. https://doi.org/10.1016/j.compedu.2012.04.015

[86] P. Sorensen, "Feedback and Assessment," Malays. J. Distance Educ., vol. 10, no. 2, pp. 85-105, 2008.

[87] S. Schuck, M. Kearney, and K. Burden, "Exploring mobile learning in the Third Space," Technol. Pedagogy Educ., vol. 26, no. 2, pp. 121-137, Mar. 2017. https://doi.org/10.1080 /1475939x.2016.1230555 
[88] Q.-F. Yang, G.-J. Hwang, and H.-Y. Sung, “Trends and research issues of mobile learning studies in physical education: a review of academic journal publications," Interact. Learn. Environ., pp. 1-19, Oct. 2018.

[89] M. Afify, "The Impact of Interaction between Timing of Feedback Provision in Distance E-Learning and Learning Styles on achieving Learning Outcomes among Arab Open University Students," Eurasia J. Math. Sci. Technol. Educ., vol. 14, no. 7, pp. 3053-3068, May 2018. https://doi.org/10.29333/ejmste/91619

[90] R. A. Kusurkar, Th. J. Ten Cate, C. M. P. Vos, P. Westers, and G. Croiset, "How Motivation Affects Academic Performance: a Structural Equation Modelling Analysis," Adv. Health Sci. Educ., vol. 18, no. 1, pp. 57-69, 2013. https://doi.org/10.1007/s10459-0129354-3

[91] A. Riswanto and S. Aryani, "Learning Motivation and Student Achievement: Description Analysis and Relationships Both," COUNS-EDU Int. J. Couns. Educ., vol. 2, no. 1, pp. 42-47, 2017. https://doi.org/10.23916/002017026010

[92] D. Sharma and S. Sharma, "Relationship between Motivation and Academic Achievement," Int. J. Adv. Sci. Res., vol. 4, no. 1, pp. 1-5, 2018.

[93] N. Golenhofen, F. Heindl, C. Grab-Kroll, D. A. C. Messerer, T. M. Böckers, and A. Böckers, "The Use of a Mobile Learning Tool by Medical Students in Undergraduate Anatomy and its Effects on Assessment Outcomes," Apr. 2019. https://doi.org/10.1002/ase.1878

[94] D. M. Gezgin, "The Effect of Mobile Learning Approach on University Students' Academic Success for Database Management Systems Course:," Int. J. Distance Educ. Technol., vol. 17, no. 1, pp. 15-30, 2019. https://doi.org/10.4018/ijdet.2019010102

[95] S. Males, F. Bate, and J. Macnish, "The Impact of Mobile Learning on Student Performance as Gauged by Standardised Test (NAPLAN) Scores," Issues Educ. Res., vol. 27, no. 1, pp. 99-114, 2017.

[96] N. A. B. Mohd Rashid, S. B. Md Salleh, and N. B. Md Noor, "Development of Jawi Spelling Skills Mobile Applications, 'Oh Jawiku,” Int. J. Interact. Mob. Technol. IJIM, vol. 13, no. 07, pp. 80-89, 2019. https://doi.org/10.3991/ijim.v13i07.10759

[97] A. I. M. Elfeky and T. S. Yakoub Masadeh, "The Effect of Mobile Learning on Students' Achievement and Conversational Skills," Int. J. High. Educ., vol. 5, no. 3, pp. 20-31, 2016. https://doi.org/10.5430/ijhe.v5n3p20

[98] M. A. M. Nawi and M. I. Hamzah, "MOBILE FATWA (M-FATWA): The Integration of Islamic Fatwa Through Mobile Technology,” Turk. Online J. Distance Educ.-TOJDE, vol. 15, no. 2, pp. 108-116, 2014. https://doi.org/10.17718/tojde.41295

[99] M. R. T. L. Abdullah and S. Siraj, "M-Learning Curriculum Design for Secondary School: A Needs Analysis,” Int. J. Educ. Pedagog. Sci., vol. 4, no. 6, pp. 1371-1376, 2010.

[100] H. B. Miller and J. A. Cuevas, "Mobile Learning and its Effects on Academic Achievement and Student Motivation in Middle Grades Students," Int. J. Scholarsh. Technol. Enhanc. Learn., vol. 1, no. 2, pp. 91-110, 2017.

[101] J. Xue, X. Zhang, and H. Luo, "Effects of Mobile Learning on Academic Performance and Learning Attitude in a College Classroom," in DEStech Transactions on Social Science, Education and Human Science, Qingdao, China, 2018, pp. 307-311. https://doi.org/10.12783/dtssehs/icaem2017/19095

[102] D. Kim, "The Impact of Learning Management Systems on Academic Performance: Virtual Competency and Student Involvement," J. High. Educ. Theory Pract., vol. 17, no. 2, pp. 23-35, 2017.

[103] S. Nair and R. Patil, "A Study on the Impact of Learning Management Systems on Students of a University College in Sultanate of Oman,” Int. J. Comput. Sci. Issues, vol. 9, no. 2, pp. 379-385, 2012. 
[104] T. Kulshrestha and A. R. Kant, "Benefits of Learning Management System (LMS) in Indian Education,” Int. J. Comput. Sci. Eng. Technol., vol. 4, no. 8, pp. 11-53-1164, 2013.

\section{Authors}

Yusuf Hanafi earned his bachelor degree in Islam education from State Islamic University of Malang, East Java Indonesia in 2000. He received an M.Fi.I degree in Islamic thought in 2003 and an Ph.D degree in Tafser \& Hadeth in 2010 from State Islamic University of Sunan Ampel Surabaya East Java, Indonesia (email: yusuf.hanafi.fs@um.ac.id). His areas of research interest include Islam education, sociology of religions, and Qur'an teaching. He is currently a lecturer of Islam education \& Qur'an teaching at the Arabic Department, Faculty of Letters, Universitas Negeri Malang (State University of Malang).

Nurul Murtadho earned his bachelor degree in Arabic education from Universitas Negeri Malang, East Java Indonesia in 1985. He received an M.Pd degree in Indonesian language education in 1991 from Universitas Negeri Malang, and an Ph.D degree in linguistic in 1999 from University of Indonesia, Jakarta. His areas of research interest include applied Linguistics and Arabic education. He is currently a professor of Arabic at the Arabic Department, Faculty of Letters, Universitas Negeri Malang.

M. Alifudin Ikhsan earned his bachelor degree (2017) and an M.Pd (2019) in civic education from Universitas Negeri Malang, East Java Indonesia. His areas of research interest include: civic education, religions, and Qur'an teaching. His is currently a teacher of civic education at Senior High School.

Tsania Nur Diyana earned her bachelor degree in Physics education from Universitas Negeri Malang in 2018. She is currently a postgraduate student at Universitas Negeri Malang in Physics education. His areas of research interest include multimedia in education, Learning Management System (LMS) and Physics education.

Article submitted 2019-07-26. Resubmitted 2019-09-27. Final acceptance 2019-09-28. Final version published as submitted by the authors. 